\title{
Between Toxics and Gold: Devaluing Informal Labor in the Global Urban Mine
}

Julia Corwin

London School of Economics and Political Science, J.E.Corwin@Ise.ac.uk

\begin{abstract}
Environmental discourses on electronic waste have converged around two framings of ewaste as a significant global concern: as a polluting and hazardous waste product, and as an under-tapped source of value: an "urban mine." This paper argues that the discursive shift between these two framings is not based in material differences between either the electronics themselves or related labor processes; instead, the major determining factor in e-waste's categorization as hazard or resource is based on the category of labor working on it and where it is located. Drawing on research in India's used electronics industry, this paper argues that when associated with informal labor in the Global South, e-waste is easily devalued and judged a hazardous waste through devaluing the labor that works on it. The conflation of pollution with informal labor in the Global South offers such a powerful narrative, particularly in governance and industry circles, that it has become a significant way to devalue e-waste in the Global South, opening up "new" frontiers of value that would otherwise be captured by local, predominantly informal, industry. Thus, environmental concerns about the hazards of e-waste can be used to secure corporate e-waste markets through devaluing informal labor.
\end{abstract}

Keywords: informal labor; devaluation; electronic waste; urban mining; refurbishment

\section{Introduction}

In late 2015 a friend in Delhi invited me to join him at a meeting with a visitor from Italy. The meeting was their first, arranged to explore potential electronic waste (e-waste) trade deals between Italy and India. The Italian man wanted to meet with e-waste dealers in Delhi to evaluate the feasibility of expanding Italy-based e-waste trade to India. His friend already conducted regular e-waste trade with informal recyclers in Brazil, and was looking for other markets in which to expand. Someone had connected him to my friend, a Delhi-based trade unionist who regularly worked with informal sector e-waste workers.

This is not, however, a straightforward story of dumping Italian e-waste in poor Indian cities for cheaper, unregulated disposal. Rather than looking to sell European e-waste into the Indian informal sector, the Italian e-waste trader was looking to buy e-waste from India and transport it back to Italy for recycling. Specifically, he wanted to buy circuit boards from smart phones. His business in Brazil exported used smart phones to Italy for recycling, and he was looking to do the same with Indian smartphones. The Italian trader said he could buy either the boards already dismantled from the phone or, if it was easier, the entire 
phone. The Indian trade unionist called a few e-waste traders in Delhi, and came back with a price per kilogram that, including shipping, was almost double what the Italian trader had initially said he was willing to pay.

It quickly became evident that the negotiation was happening with vastly different understandings of India's e-waste industry. The Italian e-waste trader had assumed he would need to set up a system in India for collection, dismantling and shipping the e-waste, as he had apparently done in Brazil. He had clearly underestimated India's e-waste industry, and had not anticipated the well-organized markets on the ground. My instinct was that the Italian's price was not remotely competitive in Delhi, and that his baseline price assumed that India's existing e-waste markets were negligible. This could not be further from the truth. I was later told that the highest quality mobile phone boards could go to Indian traders for over three times the price the Italian offered-and that didn't include international shipping and fees. I do not know if the deal was ever closed, although I left the meeting with the impression that it was unlikely.

It is not just e-waste traders that recognize the value of e-waste; e-waste is now widely understood as a source of valuable devices and materials, by critical social scientists, engineers and corporations alike. Recognizing the value of waste is not a new phenomenon, however, people who have worked with waste and depend on it for livelihoods have historically operated at the margins of society, whether they be informal waste workers in the Global South, working class laborers in the United States (Medina 2001; Nagel 2013) or waste traders (Minter 2013). The division between such marginal work and "respectable" business is much less clear now, as corporate waste management expands and waste-ascommons are actively being enclosed (Gidwani 2013; Gidwani and Corwin 2017; InverardiFerri 2018; see also Samson (this issue) on colonization and waste). Electronic waste, as a particularly valuable collection of discarded materials as well as a reportedly hazardous waste stream, is embroiled in global conflict-and not because, as is commonly reported, ewaste is being dumped in the Global South, but because informal waste workers in the Global South risk losing their already tenuous livelihoods to corporate recyclers (Reddy 2015).

This paper argues that, when associated with informal labor in the Global South, electronic waste is easily devalued and rendered hazardous waste, devaluing certain stores of e-waste through devaluing the labor that works on it. The conflation of pollution with informal labor in the Global South offers such a powerful narrative, particularly in governance and industry circles, that it has become a significant way to devalue e-waste in the Global South, opening up "new" frontiers of value that would otherwise have been captured by local, predominantly informal, industry. In this way environmental concerns about the hazards of e-waste (supposedly writ large) can be used to secure electronic waste markets in the Global North (as well as for corporate recyclers in the Global South) through devaluing informal labor processes. I argue that rather than clear material differences between either the electronics themselves or the actual work processes, the major determining factor in whether e-waste is conceived of as a hazard or resource has been 
primarily based on the category of labor and where it is located. In other words, electronic waste derives its categorical flexibility from who it is that possesses it and whether they can make claims to environmentally-safe and resource-efficient work-claims that inevitably privilege formal companies, in particular those operating in the Global North, and are central to their ability to capture e-waste otherwise circulating and being revalued in informal and local economies in the Global South.

In the following sections I discuss the value of electronic waste, in particular, precious metals imbedded in circuit boards, and the discursive and material movement of ewaste between categories of resource and hazard. I describe how reports of informal ewaste recycling in the Global South have spurred concerns about the hazards of e-waste and its handling in the informal sector, and contrast this to other important yet overlooked work done in India's informal waste economy, namely, vast waste diversion processes occurring through the reuse, repair and remanufacturing of electronics. I then discuss how legal frameworks reinforce the global separation of e-waste management labor, and show how businesses and governments in the Global North (along with formal industry in the Global South) are able to use the now-well-traveled association of informal work in the Global South as hazardous and as an environmental injustice to their own benefit. Through the discursive process of devaluing informal e-waste work in the Global South, formal and corporate recycling companies are able to re-territorialize e-waste and claim legitimacy in recovering its valuable materials.

\section{The Value of E-waste}

The successful expansion of corporate capital into the waste business depends in part on its assertion that it will solve one of the most pressing environmental problems for consumer culture today: the need to sustainably produce the many commodities expected for a good "post-industrial" life. Electronic waste is now commonly referred to as an "urban mine," which emphasizes its collection of precious and rare metals waiting to be recovered through recycling processes and its importance to a functioning circular economy. Urban mining repositions mineral deposits as having already been extracted and now collecting as "wealth on the surface" of the Earth in the form of our discarded electronics (Labban 2014, 564). The globally-valuable urban mine is present in all of our offices and houses (see Figure 1), as our used electronics become an as-yet-uncollected mine for future electronics production. Labban (2014) argues that the spatially-diffuse urban mine is more aptly called the planetary mine, while Knapp (2016) terms it the "flexible mine" to emphasize the blurring of "boundaries between extraction, production, manufacturing, consumption, and disposal" (Knapp 2016, 1890). ${ }^{1}$ The flexible mine's (re)accumulation and (re)distribution of material wealth in electronics is shaped by globally-distributed electronics production, use and disposal.

\footnotetext{
${ }^{1}$ Both Labban (2014) and Knapp (2016) note that this mine is not comfortably "urban" but rather uses the figuration of the urban to represent a division between the natural and human worlds, in which virgin mining is positioned as "spatially opposed" to urban spaces (Labban 2014, 564).
} 


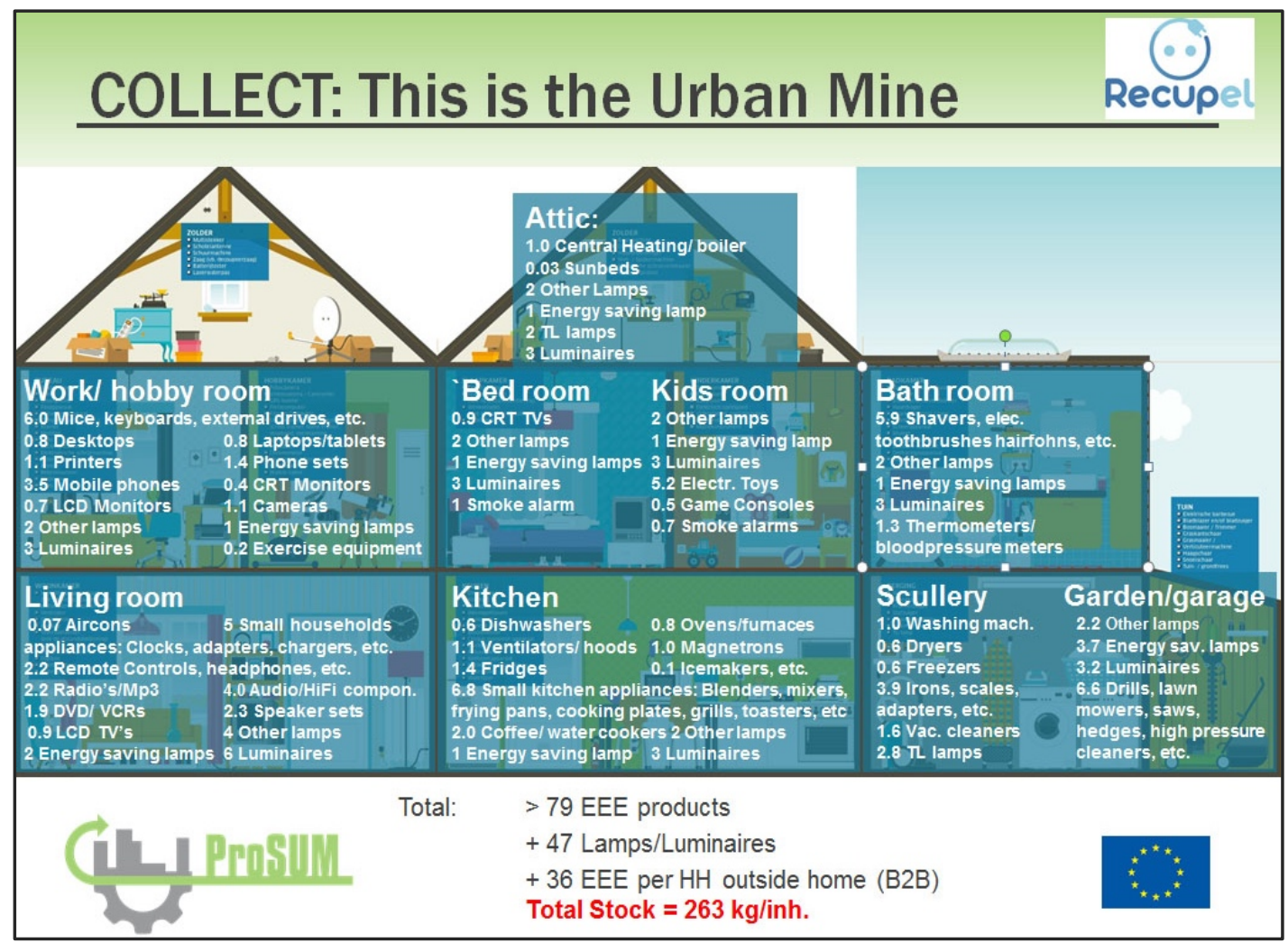

Figure 1: Diagram of the many different electronic devices from rooms in a single household. Source: PROSUM, an EU project, https://ec.europa.eu/easme/en/news/prospecting-critical-raw-materials-e-waste.

By placing value as central to understanding the movements of electronic "waste," the urban mine reveals e-waste as deeply embedded in global struggles over materials and technology. Resource recovery from e-waste can provide minerals whose extraction is lower in carbon emissions and with a reduced environmental impact than virgin mining, offering a more sustainable option for resource extraction; for example, the gold content from ewaste in 2014 represented roughly $11 \%$ of global virgin gold mining in a single year (Baldé et al. 2015, 50), and "one tonne of iPhones would deliver 300 times more gold than a tonne of gold ore and 6.5 times more silver than a tonne of silver ore" (Nogrady 2016). Smart phones are particularly rich sources of valuable materials. The US EPA estimates that one million smart phones contain 35,274 lbs. of copper, $772 \mathrm{lbs}$. of silver, $75 \mathrm{lbs}$. of palladium and 33 Ibs. of gold. ${ }^{2}$ Overall, the circuit boards from smart phones contain a higher ratio of valuable materials than those of computers, and $23 \%$ of the mass of smart phones is made up of metals (Szalatkiewicz 2014, 2368).

While municipal solid waste (MSW) has long been a concern for governments around

\footnotetext{
2 This is probably a conservative estimate, as that would mean approximately $\$ 700,000$ worth of gold at early 2018 prices, or less than $\$ 1$ of gold per smart phone. According to an expert at Sims Recycling SolutionsNorth America, a single smart phone should yield around $\$ 1.34$ worth of gold (depending on gold rates). See https://blog.dell.com/en-us/how-much-gold-is-in-smartphones-and-computers/.
} 
the world, it is only relatively recently that used electronics have been identified as a distinct waste stream and object of regulatory attention, rather than as a part of MSW. In addition to solving localized waste management problems, e-waste as a separate waste stream (in other words, the mining of e-waste) appears to offer a panacea for larger environmental concerns about rising levels of consumption, environmental injustices related to waste disposal, and the need for raw materials. However, in the West much of the so-called urban mine ends up in landfills (or incinerators), rather than being collected separately and recycled. For example, while $40 \%$ of e-waste in the European Union is reported to be collected through government recycling programs, only $12 \%$ of e-waste in the United States and $1 \%$ of e-waste in Australia was collected (Baldé et al. 2015). ${ }^{3}$ These statistics depict electronic waste, from computers and cell phones to air conditioners and wearable devices, as both an urgent environmental problem and an inefficient loss of valuable materials-all that waste is piling up in landfills or being burned in incinerators, when instead it could be mined for valuable materials.

E-waste's classificatory flexibility as both a green business opportunity and hazardous waste is not necessarily derived from material or technical differences in devices or appliances, e.g., the presence of substances like lead. All electronic devices contain materials that are potentially (or definitely) hazardous, and the extraction of valuable metals can use potentially toxic materials and techniques. This ranges from dealing with machines like CRT (cathode ray tube) monitors and TVs, which contain leaded glass, to the use of hydrochloric or nitric acid for extracting gold from circuit boards. ${ }^{4}$ Kama (2015) calls these two seemingly opposite assessments of e-waste the "logic of hazard" and the "logic of resource." Together these two logics demonstrate e-waste's ability to seemingly occupy two extremes in value simultaneously: a hazardous waste product and a source of precious metals - a literal gold mine. E-waste's designation as either toxic or valuable (when it is almost always both!) is directly tied to how it is managed. If it is managed "properly," meaning it appears that it is safely managed with adherence to environmental and labor regulations, then its value becomes its defining characteristic. If it is managed "improperly," then it is hazardous and must be treated as such. It is in this categorial flexibility that the politics of e-waste unfolds, as industry claims to proper, technocratic management of ewaste are conjoined to the overdetermination of informal work as hazardous, and together these claims help to reshape waste work as "respectable" work-as long as it excludes the informal sector in the Global South.

\footnotetext{
${ }^{3}$ Different data sources offer sometimes widely divergent estimates. For example, EPA data estimated that $40 \%$ of e-waste in the US was recycled in 2013 , up from $10 \%$ in 2000 , although this likely includes more private take-back recycling programs than the UN data (see www.electronicstakeback.com/designed-for-the-dump/ewaste-in-landfills/ for an analysis of EPA data). In general, I approach data on e-waste cautiously, and I believe it is safe to assume that the majority of e-waste in the US and EU isn't separated from MSW.

${ }^{4}$ As with most niche interests, there is now a good number of instructional videos and DIY pages that offer instructions on at-home gold recovery from electronics, including Wikihow, Instructables and Wired.
} 


\section{Producing Value in the Informal Sector}

The business of waste is not at all new. Gill $(2010,2)$ characterizes waste disposal work as "the second oldest profession in the world," noting the universal need for waste disposal and drawing a comparison between perceptions of sex work and waste work. The act of scrapping, as personal household practice as well as business, is well documented, from household practices of reusing materials and the history of scrapping industries to currentday scrap trade (see Gill 2010; Minter 2013; Strasser 1999; Zimring 2009, among others). "Scrapping," or dealing with scrap, differs in emphasis from waste management, as scrap collectors and traders place foremost the knowledge of a used thing's value rather than its need to be managed as waste. Even as solid waste has long histories of revaluation, in the 1990 s there was a clear shift in attention to e-waste as a distinct separate subset of waste. Governments and environmentalists emphasized its hazardousness, and the predominant imagery of used electronics and electronic waste became almost singularly focused on the health and environmental dangers of dumping waste in impoverished places. Reports spanning almost two decades assert that much of the West's e-waste is shipped to the Global South for cheap and unregulated recycling, positioning e-waste as a potent symbol of globalization and mass consumption, and their related human and environmental tolls (Puckett et al. 2002; Agarwal et al. 2003; Puckett, Hopson, and Huang 2016). Global environmental justice scholarship and activism quickly recognized the vast and global inequities of global trade in waste in general and e-waste in particular. ${ }^{5}$

Instead of being understood as valuable commodities, circuit boards have more commonly been invoked in concerns about the hazardous nature of the informal e-waste sector in the Global South. Defining and delineating what constitutes informality is a nuanced discussion, as evidenced, for instance by the recent wealth of scholarship on informal labor (e.g. Chen, Roever and Skinner 2016; Thieme 2018), informal land use in the Global South (e.g. Bach 2010; Roy 2009) and its relationship to the formal sector and global capital (e.g. Gregson and Crang 2017; McGrath-Champ et al. 2015). The informal used electronics sector functions through a mix of proper paperwork (tax documents, rental agreements, etc.) and informal practices (unregulated labor, land-use violations, doctored paperwork, minor tax evasion, etc.), all while intersecting with the "formal" sector and the law in multiple ways that often make such sector distinctions even more blurry. In India ewaste recycling happens primarily in the informal sector; it is widely cited that almost $95 \%$

\footnotetext{
${ }^{5}$ This has been exemplified by the Basel Action Network, an American NGO that continues to work towards ending the global trade of electronic waste. Complicating this narrative, recent studies indicate that the geographies of e-waste are constantly changing and that the geographical imagination of global e-waste flows, based in and reinforced by the Basel Convention, is no longer accurate (c.f. Furniss 2015; Lepawsky 2015b; Gregson and Crang 2015). Recent observations are that much e-waste trade is between countries in the same economic category (for example, South-South trade or trade within the European Union) and that waste "dumping" from the Global North to Global South has significantly diminished (Lepawsky 2015a; Kahhat and Williams 2012). The inaccuracies of the waste dumping narrative, and its staying power in popular media and broader e-waste discourse, have been addressed in Pickren 2014, Reddy 2015 and Tong et al. 2015, among others.
} 
of e-waste is handled informally (Chaturvedi and Bhardwaj 2013). ${ }^{6}$ In cities across the country waste provides livelihoods for some of the most marginalized city dwellers, who depend on the discards of wealthier city dwellers (the "urban mine") for survival.

Informal e-waste management in Indian cities follows similar paths to informal municipal solid waste management, in which waste is aggregated through overlapping networks of waste pickers, door-to-door waste collectors, door-to-door scrap dealers, scrap aggregators and large-scale scrap dealers and recyclers (Chintan 2007). Although concerns about e-waste focus broadly on the overall environmental and human health impacts, it is the processes for recycling circuit boards in the informal sector that produce much of the pollution and potential health problems (Mascarenhas 2016). Circuit board recycling relies on chemical processes to extract metals embedded in the boards, and these processes (burning and acid baths) are regularly cited as the cause of pollution and contamination. Reports and studies emphasize the poverty and desperation of informal e-waste labor in India and the pollution that stems from its "breaking, burning, and bathing, as well as dumping parts that cannot be further processed" with the use of "hands, aided by basic tools" (Iles 2004, 86).

Depictions of the informal e-waste sector as poor, hazardous and inefficient obscure the tremendous importance of non-recycling waste diversion through secondary use electronics industries. Interviews conducted between 2014 and 2017 with e-waste traders, repairers and recyclers in India's informal used electronics markets revealed that repair and resale of electronics, not recycling, were the most competitive e-waste-based industry. ${ }^{7}$ Refurbishment and repair work occurs across all scales of the informal-formal divide, from small, independently managed repair shops to large traders with multiple warehouses. These businesses repair, refurbish and reassemble used electronics in a well-networked industry that is more profitable and environmentally preferable to resource recovery. The significance of electronics resale markets has similarly been observed in other countries otherwise assumed to host primarily polluting informal e-waste recycling (Ejiogu 2013; Grant and Oteng-Ababio 2012; Lepawsky and Billah 2011). Because India's extended secondary markets for electronics often operate in the informal sector or are informaladjacent, this proximity has meant that they are overshadowed by reports on and fears about informal recycling.

While most attention to e-waste emphasizes responsible recycling, refurbishment and resale of electronics are a major economic driver of the electronic "waste" industry, in which devices are generally referred to as "e-waste," regardless of their age, functionality or condition. In fact, across both informal and formal used electronics markets the reuse of devices is significantly more profitable than recycling. For instance, a working phone will sell

\footnotetext{
${ }^{6}$ This statistic is based on data from before the implementation of India's E-Waste Rules, which I discuss further below. While the new Rules seek to formalize the industries, my research did not show evidence that much had changed in Delhi's informal e-waste businesses. Reddy (2013) did find evidence of significant change in Bangalore.

${ }^{7}$ I discuss the diverse processes of electronics reuse, remanufacturing and repair in detail in Corwin (2018).
} 
for more than the materials contained within it, and "recycling" companies across the world prioritize the repair and resale of electronics rather than recycling and the recovery of their materials. A recent report by a technology industry analysis firm, Counterpoint, confirms the growing significance of electronics refurbishment and the importance of "second life" smartphones in global electronics markets. Their research indicated that in 2017 the global sales of refurbished smartphones grew faster than sales of new smartphones, and that sales of used smartphones made up almost $10 \%$ of the global smartphone market (Kang 2018). Used high end smartphones like iPhones often rival or beat the quality of low to mid-level smartphones, and often outcompete new smartphone sales (Dilger 2018).

The lucrative refurbishment sector is growing across the world. In India two of the leading e-waste recycling companies, both of whom emphasize their advanced recycling technology and safe labor practices, have strong refurbishment operations. In North India Attero operates Atterobay.in, through which it buys and sells used mobile phones, and EParisaraa has a factory devoted to "assets recovery" in which items are repaired and resold. ${ }^{8}$ Internationally, Sims Recycling Solutions (a part of the larger Sims Metal Management recycling company, the world's leading publicly listed metal and electronics recycler) advertises its services as a skilled refurbisher of electronics in addition to its recycling capabilities. Across the world, refurbishment work consists of similar work processes. I saw comparable work happening across Delhi's informal used electronics businesses as was conducted in an e-waste recycling factory in St. Paul, Minnesota: components tested, certain devices upgraded, "new" products made from old parts, and a host of repair and refurbishment processes that gave new life to old electronics.

Refurbishment is accomplished through similar labor processes regardless of where it takes place, thus complicating-and perhaps superseding-debates on informal labor and pollution from e-waste recycling in the Global South. This does not mean that some aspects of informal e-waste handling in India (and in other countries) are not hazardous, and it is not meant to delegitimize genuine concern about the environmental and health effects of some recycling processes; nor am I arguing that waste does not often travel to poorer areas or is not managed by poor communities. Instead, the significance of reuse and repair (or "assets recovery") to used electronics markets resets the conversation on waste in the Global South and shows the inadequacy of simple distinctions between informal and formal work, or work processes in the Global South and Global North. Overall, refurbishment work is significantly less hazardous than recycling work, and my observation of refurbishment work in both India and the United States does not indicate the work would be significantly more dangerous in India. While data on workplace injuries are difficult to come by, I believe repair and refurbishment would be subject to general workplace hazards that are common to industrial work in the Global North, from repetitive stress injuries to the hazards of working with bulky materials.

Moreover, work in Western countries-particularly work with waste-is not

\footnotetext{
${ }^{8}$ Interview, Bangalore, July 13, 2016.
} 
inevitably safe or "green," even as governments and companies present it as so. Gregson et al. $(2016,543)$ not only disabuse us of the notion that recycling work in the EU is clean and green but argue that the work is in fact "dirty, often demeaning, physically demanding and in some cases, dangerous; added to which it is extremely lowly paid." Waste scholars have continuously contested the assumption of any complete and safe waste management, even as "zero waste" movements and circular economies have gained visibility in mass media (see, for example, Balch 2016). The mythology of neatly manageable (or already managed) waste and techno-efficiency in the Global North continues to haunt actual waste "management," while simultaneously providing support for waste management companies that lay claim to the mythology (Demaria and Schindler 2016; Gidwani and Corwin 2017).

\section{Devaluing Informal Work and Corporate Capture of the Urban Mine}

Reterritorializing things already dismissed as waste hinges on the ways in which electronic "waste" can be materially, legally and discursively transformed into value. Gille $(2007,34)$ argues that how waste is dealt with is shaped by social and political approaches to waste and not necessarily the materiality of the waste itself, and that different waste regimes (based in the "production, representation, and politics of waste") shape different management systems. She thus argues that different metaconcepts of waste must be identified and challenged. Garcier $(2012,83)$ similarly identifies recycling narratives of nuclear waste as based in-and further reifying-ideas of nuclear waste as recyclable or of a "closed nuclear cycle" which liken "the 'uranium cycle' to other great fundamental natural cycles - the cycles of water, nitrogen and carbon-and thus suggests that, throughout the cycle, matter is conserved at an atomic level." These narratives extend to waste-based labor, too. The conflation of informal labor in the Global South and hazardous work provides a narrative for electronic waste that serves to negatively juxtapose informal work to the supposedly clean and safe work in the Global North or the formal, corporate recycling sector, what Reddy $(2015,170)$ refers to as the production of the "abject Other of the formal sector." While waste work in the Global North is depicted as based in technopolitical management systems, absent of pollution problems or dirty labor, waste work in the Global South is entirely overdetermined by descriptions of dirt, pollution and abject, desperate poverty (see e.g. Gidwani 2015; Kornberg 2019).

In waste management, what is "hazardous" and therefore must be disposed of separately from non-hazardous waste is not always clear, and environmental regulations regularly change according to industry practices and technical debates, along with political decisions. Often governments do not categorize e-waste as hazardous but as containing hazardous materials and components (this is true for the EU and US), while some specific devices may be considered hazardous (such as CRT TVs and monitors and some batteries). ${ }^{9}$

\footnotetext{
${ }^{9}$ For example, according to US EPA regulations on waste, hazardousness is based on four categories: corrosivity, ignitability, reactivity and toxicity. This means that in the United States, not all battery waste is generally considered hazardous (specifically, alkaline batteries are not). In the US there is no national law
} 
Despite the complexity of ways that used electronics are categorized, revalued and recycled globally, governance of electronic waste reinforces the link between informal labor in the Global South and the hazards of e-waste. The Basel Convention on the Control of Transboundary Movements of Hazardous Wastes and their Disposal stands as the primary global intervention designed to account for the global movement of wastes and correct global inequities that have positioned the Global South as a sink for hazardous waste. The Basel Convention, which entered into force in 1992, regulates the trade of hazardous waste from developed countries to less developed countries (LDCs).

Prompted by concerns about informal recycling practices and reports of regular ewaste exports from the West, in 2011 India established nationwide regulation on e-waste handling. Drafted with feedback from environmental NGOs, European development agencies and industry associations, the intention of the E-waste (Management and Handling) Rules was to ensure proper handling of e-waste, in part by requiring formalization of the e-waste industry and making all informal or unauthorized e-waste work illegal. Interviews with senior policy makers in Delhi indicated that the Rules (recently updated in 2016) were designed to prevent any opportunity for e-waste to move into the informal sector and to ensure proper flows of e-waste to a government-authorized collector, dismantler or recycler. The Indian government provides authorization to formal e-waste recycling companies who, similar to recycling companies in the West, have installed expensive industrial recycling infrastructure, have clean professional websites that assert their "green" credentials, and focus on the many services they provide to companies disposing of electronics. Taken together, the global governance of the Basel Convention and national regulations like India's E-waste Rules show a pattern of understanding e-waste as a waste product rather than a resource with a diverse set of possible uses and future values. The regulatory focus on e-waste's management and safe disposal generally means preventing the informal sector from accessing it. These forms of environmental governance view used electronics as indisputably waste in need of monitoring to ensure its safe recycling or disposal.

In an analysis of the European Union's policy regarding e-waste, Kama $(2015,16)$ notes that it "stands out as an extensive attempt to shift the bottom line of capitalism, aimed at reversing the flows of externalities and returning them to the heart of market exchange." Reversing the flows of these waste externalities entails shifting things circulating outside corporate or formal capital into its "heart"; governance of electronic waste as hazardous and informal labor as inefficient and polluting does just that, assisting in the dispossession of waste-as-value from informal workers across the Global South (Schindler, Demaria and Pandit 2012; Samson 2015; Inverardi-Ferri 2018; Tuçaltan (this issue)). The discourse of environmental "improvement" enables the process of disciplining the waste matter through primitive accumulation, turning it into "potential capital" (Goldstein 2013). These forms of regulating e-waste management provide legal and discursive fuel for formal,

governing electronic waste and it is regulated at the state level (and sometimes at the municipal level), creating a patchwork of laws. 
corporate capital to accumulate e-waste from informal workers in the Global South: primitive accumulation that functions by reasserting the supposed primitive nature of the informal sector.

As demonstrated by the robust electronics repair and resale sectors in India, India's informal industry is certainly not "primitive." The urgency of corporate capital's efforts to access and accumulate e-waste is in part driven by the efficiency of informal waste management. The first step towards recycling is to amass the recyclables together, and informal recycling networks are uniquely efficient at scrap collection. Formal e-waste recyclers and policy makers in India have lamented that corporate recyclers have trouble competing with the informal sector because of the efficiency of informal waste collection, in particular because its local organization provides efficient last-mile collection and their ability to offer better prices for e-waste (personal correspondence). ${ }^{10}$ The informal sector's efficiency, coupled with the low collection rates for electronic waste in Western countries and by formal recyclers in the Global South, means that corporate recyclers must rely on discourses of clean, safe and environmentally-friendly work to compete with the informal sector and accumulate quantities of used electronics. Their claims to being the sole source of responsible recycling requires the devaluation of the work in India and other countries in the Global South (c.f. Noyes 2014; Scruggs 2018), opening new paths for the accumulation of e-waste.

Two narratives are significant to reinforcing the stigmatization of informal resource recovery work in India: that it is polluting and that it is inefficient and therefore wastes precious resources. Both of these rely on the condemnation of informal work, which allows them to ignore non-polluting work processes such as the repair of used electronics along with the efficiency of informal waste collection. Government-authorized recyclers in India and recycling companies in the United States openly justify their businesses as environmentally responsible, in comparison with how recycling is done in the informal sector (and sometimes more broadly in the "Third World"). The narrative of e-waste as a global environmental injustice plays a major role in advertisements and claims to their importance and legitimacy in capturing these resources. In India formal and corporate waste management companies implicitly-and often explicitly-compare themselves favorably to informal recyclers. For example, one of the "e-waste facts" presented on Attero's website is that "76 per cent workers in informal recycling operations in India suffer from respiratory ailments like asthma, bronchitis, choking, coughing, irritation, breathing difficulties and tremors among others," implying that formal recycling workers do not have respiratory problems. ${ }^{11}$

\footnotetext{
${ }^{10} \mathrm{E}$-waste, like other scrap materials, is always bought and sold in India; while formal e-waste recyclers often argue that the informal sector can offer better prices because of the cheap and hazardous methods of recycling, my observation was that the informal sector's diversified reuse industries are what drove the higher prices.

${ }^{11}$ See http://www.attero.in/about-us.html.
} 
Similarly, at a tour of a recycling factory in Minnesota, ${ }^{12}$ an introduction by the Vice President of the company began by explaining what they were not: they were not like recyclers in developing countries that depend on child labor, where people are exposed to chemicals and heavy metals and no health precautions are taken. The VP barely described his own company separately from the traditional narrative of e-waste as toxic; instead, they were presented as the clean and technically-efficient alternative to work in poor countries. He also compared his company favorably to virgin mining operations (specifically gold mining in the Congo) which, he asserted, had similarly terrible health and environmental practices to informal e-waste recycling. The Minnesotan e-waste recycling company not only emphasized its comparative superiority to work in the Global South, but also indicated its importance to urban mining. The VP asserted that his company helped to keep "our" resources "here" rather than sending them abroad for recycling (since the tour was for a group of Americans, I took this discussion to be about conserving resources in the American national interest).

Environmental reports and formal companies also invoke the inefficiency of the informal sector's recycling as justification for formal and corporate electronics recycling. Metals recovery in the informal sector is generally reported to be inefficient (Puckett, Hopson, and Huang 2016), with recovery "carried out only for valuable metals such as gold, silver, aluminum, and copper" and not for "other materials such as tantalum, cadmium, zinc, and palladium" (Borthakur 2015, 227). These justifications often neglect to mention collection inefficiency in the Global North, where large quantities of e-waste end up in the landfill or incinerator, much less the efficiency of reuse and repair as compared to intensive recycling practices. Instead, the environmental significance of a move from virgin mining to "urban" mining is lauded across environmental and business circles, presented as fulfilling the promise of sustainable living alongside sustained commodity production.

The urban mine offers a discursive win-win to the supposed problem of informal recycling as well as the global need for materials. For example, an article in Fortune on a California-based startup BlueOak Resources, which bills itself as the first American urban mining refinery, speculates that urban mining can "solve the world's e-waste problem," comparing the California company favorably to informal recycling in Guiyu, China (Noyes 2014). In addition to (supposedly) solving the e-waste "problem," urban mining provides hope for "green" business: a zero-waste or closed-loop solution to commodity production, in which the materials recovered from the bodies of old electronics are directly incorporated into the manufacturing of new products. The environmental importance of urban mining depends on the recovery of materials as compared to energy-intensive virgin mining - and the unspoken necessity of accumulating materials from the informal sector and shifting them to formal circulations of commodity production. ${ }^{13}$

\footnotetext{
12 Visit on November 14, 2012.

${ }^{13}$ The history of colonial relationships and virgin mines continues to this day in global e-waste politics. Umicore, a major e-waste recycler, is the most recent corporate iteration of Union Minière du Haut-Katanga, a colonial mining company that operated copper mines in the former Belgian Congo. Union Minière rebranded
} 
E-waste recycling now has its own day. A European e-waste recyclers association, the WEEE Forum, designated October 13, 2018 as the first International E-waste Day, with the association's goal being to "raise the public profile of e-waste recycling and encourage consumers to recycle their e-waste ... on the day itself and into the future." ${ }^{14}$ One can assume that International E-waste Day does not celebrate informal e-waste management and its diverse waste-diversion practices. Instead, it raises the profile of corporate recyclers and their claims to "green" recycling. Defining what is "waste" (and when it is waste) is thus a political act that marks waste as a "terrain of power," rather than a material with specific attributes (Gille 2007, 37). The moral legitimacy in e-waste handling, and therefore control over resources, is consistently claimed by formal, corporate companies-and often predominately by countries in the Global North - through the active devaluation of informal labor. In the global commodity trade of "waste" products, the line between waste and value is disproportionately shaped by waste management law and discourse on responsible, technocratic waste management, both of which actively devalue labor in the informal sector. Attending to how e-waste shifts between waste and resource reveals the nature of this discursive manipulation, namely that e-waste regulations and narratives of environmental justice serve as lucrative mechanisms for opening access to used electronics markets otherwise dominated by the informal sector. The political power to regulate how "waste" is remade into a valuable commodity offers a potentially dramatic return on investment as electronic waste can undergo a sudden discursive shift from hazardous waste to a gold mine. These political battles produce new commodity frontiers and territories, and new battlegrounds over how these are defined, legislated, and who captures them in the end.

\section{Acknowledgements}

Thanks to all the e-waste and used electronics traders, recyclers and workers who allowed me to enter their worlds, and to Shashi Pandit for inviting me to the meeting with the Italian trader. My thanks as well to Federico Demaria and Seth Schindler for their helpful comments, as well as to two anonymous reviewers for theirs.

\section{References}

Agarwal, Ravi, Rakesh Ranjan and Papiya Sarkar. 2003. Scrapping the Hi-Tech Myth:

Computer Waste in India. New Delhi: Toxics Link.

Bach, Jonathan. 2010. "'They Come in Peasants and Leave Citizens': Urban Villages and the Making of Shenzhen, China." Cultural Anthropology 25 (3): 421-458.

Balch, Oliver. 2016. "A World without Waste: The Rise of Urban Mining." The Guardian,

itself as a "specialty materials company" in the 1990s and completely divested from mineral extraction by the mid-2000s. Umicore now refers to itself as a "global materials technology and recycling group" with a turnover of $€ 11.1$ billion, according to its website (http://www.umicore.com/en/about/history - today).

${ }^{14}$ See http://https://weee-forum.org/iewd-about/. 
October 25. https://www.theguardian.com/sustainable-business/2016/oct/25/urbanmining-recyling-waste-buildings-offices-cities.

Baldé, C.P., F. Wang, R. Kuehr, and J. Huisman. 2015. The Global E-waste Monitor - 2014. Report. Bonn: United Nations University.

Borthakur, Anwesha. 2015. "Generation and Management of Electronic Waste in India: An Assessment from Stakeholders' Perspective." Journal of Developing Societies 31 (2): 220-248.

Chaturvedi, Bharati, and Supriya Bhardwaj. 2013. Learning to Re-E-Cycle: What Working With E-waste Has Taught Us. New Delhi: Chintan Environmental Research and Action Group.

Chen, Martha, Sally Roever, and Caroline Skinner. 2016. "Editorial: Urban Livelihoods:

Reframing Theory and Policy." Environment and Urbanization 28 (2): 331-342.

Chintan Environmental Research and Action Group. 2007. Wasting our Local Resources: The Need for Inclusive Waste Management Policy In India. New Delhi: Chintan Environmental Research and Action Group.

Corwin, Julia Eleanor. 2018. "'Nothing Is Useless in Nature': Delhi's Repair Economies and Value-Creation in an Electronics 'Waste' Sector." Environment and Planning A 50 (1): 14-30.

Demaria, Federico, and Seth Schindler. 2016. "Contesting Urban Metabolism: Struggles Over Waste-to-Energy in Delhi, India." Antipode 48 (2): 293-313.

Dilger, Daniel Eran. 2018. "Refurbished, High-end iPhones Are Suffocating the Growth of Cheap New Androids." Apple Insider, March 14.

https://appleinsider.com/articles/18/03/14/refurbished-high-end-iphones-aresuffocating-the-growth-of-cheap-new-androids.

Ejiogu, Amanze Rajesh. 2013. "E-Waste Economics: A Nigerian Perspective." Management of Environmental Quality: An International Journal 24 (2): 199-213.

Furniss, Jamie. 2015. "Alternative Framings of Transnational Waste Flows: Reflections Based on the Egypt-China PET Plastic Trade." Area 47 (1): 24-30.

Garcier, Romain. 2012. "One Cycle to Bind Them All? Geographies of Nuclearity in the Uranium Fuel Cycle." In Economies of Recycling: Global Transformations of Materials, Values and Social Relations, edited by Catherine Alexander and Joshua Reno, 76-97. London: Zed Books.

Gidwani, Vinay. 2013. "Six Theses on Waste, Value, and Commons." Social and Cultural Geography 14 (7): 773-783.

Gidwani, Vinay. 2015. "The Work of Waste: Inside India's Infra-Economy." Transactions of the Institute of British Geographers 40 (4): 575-595.

Gidwani, Vinay, and Julia Corwin. 2017. "Governance of Waste." Economic \& Political Weekly 52 (31): 44-54.

Gill, Kaveri. 2010. Of Poverty and Plastic: Scavenging and Scrap Trading Entrepreneurs in India's Urban Informal Economy. New Delhi: Oxford University Press. 
Gille, Zsuzsa. 2007. From the Cult of Waste to the Trash-Heap of History: The Politics of

Waste in Socialist and Post-Socialist Hungary. Bloomington: Indiana University Press.

Goldstein, Jesse. 2013. "Terra Economica: Waste and the Production of Enclosed Nature."

Antipode 45 (2): 357-375.

Grant, Richard, and Martin Oteng-Ababio. 2012. "Mapping the Invisible and Real 'African'

Economy: Urban E-Waste Circuitry." Urban Geography 33 (1): 1-21.

Gregson, Nicky, and Mike Crang. 2015. "From Waste to Resource: The Trade in Wastes and

Global Recycling Economies." Annual Review of Environment and Resources 40: 151-

176.

Gregson, Nicky, and Mike Crang. 2017. "Illicit Economies: Customary Illegality, Moral

Economies and Circulation." Transactions of the Institute of British Geographers 42 (2):

206-219.

Gregson, Nicky, Mike Crang, Julie Botticello, Melania Calestani, and Anna Krzywoszynska.

2016. “Doing the 'Dirty Work' of the Green Economy: Resource Recovery and Migrant

Labour in the EU." European Urban and Regional Studies 23 (4): 541-555.

lles, Alastair. 2004. "Mapping Environmental Justice in Technology Flows: Computer Waste

Impacts in Asia." Global Environmental Politics 4 (4): 76-108.

Inverardi-Ferri, Carlo. 2018. "The Enclosure of 'Waste Land': Rethinking Informality and

Dispossession." Transactions of the Institute of British Geographers 43 (2): 230-244.

Kahhat, Ramzy, and Eric Williams. 2012. "Materials Flow Analysis of E-Waste: Domestic

Flows and Exports of Used Computers from the United States." Resources,

Conservation and Recycling 67: 67-74.

Kama, Kärg. 2015. "Circling the Economy: Resource-Making and Marketization in EU

Electronic Waste Policy." Area 47 (1): 16-23.

Kang, Tom. 2018. "The Surprising Growth of Used Smartphones (Press Release)."

Counterpoint Research. March 7. https://www.counterpointresearch.com/surprisinggrowth-used-smartphones/

Knapp, Freyja L. 2016. "The Birth of the Flexible Mine: Changing Geographies of Mining and the E-Waste Commodity Frontier." Environment and Planning A 48 (10): 1889-1909.

Kornberg, Dana. 2019. "Garbage as Fuel: Pursuing Incineration to Counter Stigma in Postcolonial Urban India." Local Environment 24 (1): 1-17.

Labban, Mazen. 2014. "Deterritorializing Extraction: Bioaccumulation and the Planetary Mine." Annals of the Association of American Geographers 104 (3): 560-576.

Lepawsky Josh. 2015a. "The Changing Geography of Global Trade in Electronic Discards:

Time to Rethink the E-Waste Problem." Geographical Journal 181 (2): 147-159.

Lepawsky, Josh. 2015b. “Are We Living in a Post-Basel World?” Area 47 (1): 7-15.

Lepawsky, Josh, and Mostaem Billah. 2011. "Making Chains That (Un)make Things: Waste-

Value Relations and the Bangladeshi Rubbish Electronics Industry." Geografiska

Annaler: Swedish Society for Anthropology and Geography 93 (2): 121-139. 
Mascarenhas, Ozzie, Doris D’Souza, and S. George. 2016. “Ethics of E-Waste Management: An Input-Process-Output Analytic Approach." Management and Labour Studies 41 (1): 1-18.

McGrath-Champ, Susan, Al Rainnie, Graham Pickren, and Andrew Herod. 2015. "Global

Destruction Networks, the Labour Process and Employment Relations." Journal of Industrial Relations 57 (4): 624-640.

Medina, Martin. 2001. "Scavenging in America: Back to the Future?" Resources, Conservation and Recycling 31 (3): 229-240.

Minter, Adam. 2013. Junkyard Planet: Travels in the Billion Dollar Trash Trade. New York: Bloomsbury Press.

Nagel, Robin. 2013. Picking Up: On the Streets and Behind the Trucks with the Sanitation Workers of New York City. New York: Farrar, Straus and Giroux.

Nogrady, Bianca. 2016. "Your Old Phone is Full of Untapped Precious Metals". BBC, October

18. http://www.bbc.com/future/story/20161017-your-old-phone-is-full-of-preciousmetals.

Noyes, Katherine. 2014. “Can 'Urban Mining' Solve the World's E-waste Problem?” Fortune, June 26. http://fortune.com/2014/06/26/blueoak-urban-mining-ewaste/.

Pickren, Graham. 2014. "Political Ecologies of Electronic Waste: Uncertainty and Legitimacy in the Governance of E-Waste Geographies." Environment and Planning A 46 (1): 2645.

Puckett, Jim, Leslie Byster, Sarah Westervelt, Richard Gutierrez, Sheila Davis, Asma Hussain, Madhumitta Dutta. 2002. Exporting Harm: The High-Tech Trashing of Asia. Seattle:

Basel Action Network. February. https://www.ban.org/s/Exporting-Harm-Report.pdf.

Puckett, Jim, Eric Hopson, and Monica Huang. 2016. Disconnect: Goodwill and Dell,

Exporting the Public's E-Waste to Developing Countries. Seattle: Basel Action Network.

Reddy, Rajyashree N. 2013. "Revitalising Economies of Disassembly: Informal Recyclers,

Development Experts and E-Waste Reforms in Bangalore." Economic \& Political Weekly xlviii (13): 62-70.

Reddy, Rajyashree N. 2015. "Producing Abjection: E-Waste Improvement Schemes and Informal Recyclers of Bangalore." Geoforum 62: 166-174.

Roy, Ananya. 2009. "Why India Cannot Plan Its Cities: Informality, Insurgence and the Idiom of Urbanization." Planning Theory 8 (1): 76-87.

Samson, Melanie. 2015. "Accumulation by Dispossession and the Informal Economy Struggles over Knowledge, Being and Waste at a Soweto Garbage Dump." Environment and Planning D: Society and Space 33 (5): 813-830.

Samson, Melanie. This issue. Whose Frontier Is It Anyway? Reclaimer 'Integration' and the Battle over Johannesburg's Waste-based Commodity Frontier. Capitalism Nature Socialism 31(1).

Schindler, Seth, Federico Demaria, and Shashi B. Pandit. 2012. "Delhi's Waste Conflict." Economic \& Political Weekly xlvii (42): 18-21.

Scruggs, Gregory. "United Nations CITO Believes Tech Can Solve Some of the World's Biggest 
Challenges if the Private Sector Steps Up." GeekWire, May 2.

https://www.geekwire.com/2018/united-nations-cito-believes-tech-can-solve-worldsbiggest-challenges-private-sector-steps/.

Strasser, Susan. 1999. Waste and Want: A Social History of Trash. New York: Holt

Paperbacks.

Szalatkiewicz, Jakub. 2014. "Metals Content in Printed Circuit Board Waste." Polish Journal of Environmental Studies 23 (6): 2365-2369.

Thieme, Tatiana Adeline. 2018. "The Hustle Economy: Informality, Uncertainty and the Geographies of Getting By." Progress in Human Geography 42 (2): 529-548.

Tong, Xin, Jingyan Li, Dongyan Tao, and Yifan Cai. 2015. "Re-Making Spaces of Conversion: Deconstructing Discourses of E-Waste Recycling in China." Area 47 (1): 31-39.

Tuçaltan, Gül. This issue. Waste and Metropolitan Governance as Vehicles of Eviscerating Urbanism: A Case from Ankara. Capitalism Nature Socialism 31(1).

Zimring, Carl A. 2009. Cash for Your Trash: Scrap Recycling in America. New Brunswick, NJ: Rutgers University Press. 